\title{
Comparative Analysis of Cartographic Literacy in the Selected Curricula at the Primary Level
}

\author{
Vlasta Hus, Tina Hojnik \\ Department of Primary Education, University of Maribor, Maribor, Slovenia \\ Email: vlasta.hus@uni-mb.si
}

Received October 22 $2^{\text {nd }}, 2013$; November 22 $2^{\text {nd }}, 2013$; accepted November $29^{\text {th }}, 2013$

\begin{abstract}
Copyright $(\odot 2013$ Vlasta Hus, Tina Hojnik. This is an open access article distributed under the Creative Commons Attribution License, which permits unrestricted use, distribution, and reproduction in any medium, provided the original work is properly cited. In accordance of the Creative Commons Attribution License all Copyrights (C) 2013 are reserved for SCIRP and the owner of the intellectual property Vlasta Hus, Tina Hojnik. All Copyright (C) 2013 are guarded by law and by SCIRP as a guardian.
\end{abstract}

\begin{abstract}
Basic knowledge of maps, because of its widespread use, has become a part of the individual's modern literacy. This is why we were interested in how this kind of literacy which is represented in schools, when it occurs and how it is upgraded. Based on the study of literature we have formed criteria of cartographic literacy and based on the comparative method we have compared and curricula for the lower stage of primary education of two countries (England and Slovenia). We found that cartographic literacy is given most attention, as well as in content of in didactic recommendations, in the Slovene curriculum for Social Studies (second triad). But according to the pupils' cognitive abilities, it is being introduced too late. In the English curriculum for Geography initial cartography is far more dependent on the teachers and their cartography knowledge (or lack of it) because of the general definition of objectives and lack of recommendations. A combination of such an open curriculum and teacher's cartography knowledge (or lack of it) can push cartographic literacy a step back from other content. That is why educating teachers and paying attention to the matter either in the curriculum or in textbook sets are of utmost importance.
\end{abstract}

Keywords: Curricula; Primary Level of Education; Cartographic Literacy

\section{Introduction}

Maps are a highly concentrated source of information and an important information-communication means. They are a basic tool for learning and understanding of Earth's surface and objects on it and means of acquiring a variety of knowledge and information. We use them at almost every step, e.g. knowledge of World's geography, travelling to remote places, reading roadmaps, familiarization with weather imagery, etc. For obtaining reading techniques and communication with the maps the term cartographic literacy was therefore introduced. Its intention was to train an individual for a flawless use of maps, which means that the user must comprehend its content, interpret it and also visualize displayed area.

Cartographic literacy is a complex mental activity and as such a long-term process. Its success depends on several factors (e.g. on child's age, his mental development, needs, experiences; quality of used maps, etc.). Basic techniques and skills to read maps are differently defined in literature. Mostly they classify them as comprehension of perspective, orientation and direction, comprehension of map scale, cartographic language and land relief (Umek, 2001a). In acquiring these basic elements pupil passes through three levels of difficulty, namely material level (collecting concrete experiences about space), cartographic level (conversion of these experiences into parts of the map) and only then carrying out thought processes on an abstract level (Verhetsel, 1994).

Cartographic literacy is a part of functional literacy therefore at least the same amount of attention should be given to map comprehension as it is given to reading literacy. This led us to explore teaching cartographic literacy in schools in two countries, namely Slovenia and England. We focused on the primary level of education. Decision was based on the reviewed literature where we determined that children are already capable to comprehend many properly adjusted map components in the pre-school period. In the curricula we reviewed cartographic objectives and basic cognitions of this field (when and how they are included in the curricula of both countries). We were also interested in the support that curricula offer teachers in didactic recommendations, teaching methods, forms and techniques. We were also interested in what kind of autonomy curricula grant the teachers and what kind of influence it has on cartographic literacy.

\section{Methodology}

Descriptive analysis was used based on the study of professional literature. Reviewed literature refers to so far existing general didactic findings and to narrow didactic findings of geography and psychology on cartographic literacy. We used the comparative method of scientific educational research. This was used to compare cartographic literacy on the primary level from Slovene curricula for the Environmental Studies (Kolar, Kostanjšek, Krnel, Pertič, Umek, \& Velkavrh, 2011) and Social Studies subject (Budnar, Hus, Kerin, Kos, Mirt, Raztresen, \& Umek, 2011) as well as from the English curriculum for Geog- 
raphy (The National Curriculum for England. Geography, 1999). This was done with the intention of discovering similarities and differences. For comparative analysis we prepared the criteria in advance and while forming them we derived from basic criteria of the curricula and from basic components of cartographic literacy as defined by Umek (2001a). The latter was described in detail during the article:

1) An overview of the objectives and basic skills for the cartography classes in the selected curricula.

2) The integration of the basic components of cartographic literacy in the selected curricula.

3) The contents of the objectives that foresee use, reading, drawing and interpretation of maps.

4) Teachers' autonomy, teaching forms, methods and techniques for teaching initial cartography in the selected countries.

5) Didactic recommendations and additional help for the teachers of cartographic literacy.

In the sample of comparison we included the first and the second educational period in England which is comparable across time with the class level or the first and partly second triad of Slovene nine-year primary school. We compared criteria according to pupils' age level - it means that we compared the first educational period (Key stage 1) in England (children aged five to seven years) with the first class of Slovene nineyear school (children aged six to seven years). Second educational period (Key stage 2) in England (children aged seven to eleven years) was compared with second, third, fourth and fifth grade of the Slovene nine-year school (children aged seven to eleven years). We should explain that pupils in England are admitted to school at the age of five and in Slovenia at the age of six. This type of schooling in England is three years longer and is divided into four educational periods and in Slovenia into three trienniums.

\section{An Overview of the Objectives and Basic Skills for the Cartography Classes in the Selected Curricula}

In the reviewed curricula we searched for cartographic objectives and basic cognitions of cartography and we compared their number, content and vertical upgrade. The objectives in the English curricula are written in the form of reference points, namely for each educational period. The objectives in the Slovene curricula are precisely defined and written for each grade separately but with the curricula reform they have stayed only as a recommendation where teacher himself decides whether it will be implemented as it is recommended or at a slower or faster pace.

Basic cognitions are knowledge, skills and comprehensions that pupils should acquire at the end of certain educational period. Similar to objectives basic cognitions from cartographic literacy are more precisely defined in the Slovene curricula whereas English basic cognitions are more general and do not specifically apply to cartographic literacy. Discussed basic cognitions are consistently upgraded in curricula of both countries.

There are few cartographic objectives and basic cognitions in the reviewed curricula especially in the first age period (five to seven years). Here we found three objectives and three basic cognitions regarding cartography in the Slovene curriculum, and in English curriculum there were eight objectives and six basic cognitions that can be associated with cartography. In the second age period (seven to eleven years) we found twenty-one objectives and fifteen basic cognitions of cartography and in English there were ten objectives and five basic cognitions that can be associated with cartography.

The difference in content among the discussed objectives for the first educational period in the curricula of both countries is that pupils in England get acquainted with a greater cognitive space earlier than their peers in Slovenia and English pupils (up to seven years of age) also learn about not only natural (as it is foreseen in the Slovene curriculum) but also about social characteristics of local landscape. Both are compared to the so called contrastive landscape. The advantage of the latter is a better understanding of discussed characteristics and awareness about places outside of local landscape. In Slovene curricula a similar objective is stated among basic cognitions that pupils should acquire a bit later (up to nine years of age).

The content of the objectives that can be associated with cartographic literacy in the second age period (seven to eleven years) is similar in the curricula of both countries, except that in the Slovene curricula they are more concretely defined. In both countries broadening of cognitive space from local landscape to landscapes around the world is expected, as well as describing and identifying natural and social characteristics of discussed landscapes; using various strategies, primary and secondary sources to learn about landscapes where they base their exploration on their knowledge.

\section{The Integration of the Basic Components of Cartographic Literacy in the Selected Curricula}

As mentioned before we have taken the basic components of cartographic literacy after Umek (2001a), namely bird perspective, orientation, cartographic symbols, land relief and map scale. We were interested for which age level of the pupils and in which way these basic components are foreseen and included in the curricula.

Slovene curriculum (for pupils up to seven years of age) does not explicitly foresee basic components (only drawing of landscape characteristics is mentioned), and English curriculum mentions one activity associated with orientation (use of geographic vocabulary - north and south). For pupils (aged seven to eleven) Slovene curricula foresee twelve objectives associated with the use of basic components of a map (from total of twenty-two cartographic objectives) and English curriculum mentions one of a total of ten cartographic objectives. Recommendations related to the methods of implementing the basic map elements were not detected in the reviewed curricula. Their implementation is therefore dependent on the teacher, his knowledge of basic components, and use of additional literature as well as recommendations and activities that might be stated in the textbook sets.

Bird perspective is one of the basic elements of cartographic literacy. Children can understand this intuitively in the preschool period if it shows objects, phenomena and spaces familiar to them (Umek, 2001a). In the reviewed curricula there was no objective that explicitly mentions bird perspective, only the use of aircraft photograph is mentioned. In the English curriculum this is foreseen for children up to seven years of age, and in Slovene not before nine years (stated as a basic notion). It would be reasonable to consider emphasizing aircraft photographs and introducing them into classes earlier because children as young as five to six years can successfully identify 
space or place with the help of aircraft photograph (they can successfully estimate direction as well, the only problem is estimating distances) (Blades, Plester, \& Spencer, 2003). In one of her research Umek (2001a) even found that children were more successful in using aircraft photographs than in using maps. And it is important that because of the use of photographs their efficiency in using maps has improved as well.

Orientation is also one of the basic elements of cartographic literacy. Orientation is closely related to cartography that is why we would expect to find more of these objectives in the reviewed curricula.

As with bird perspective children in pre-school period are good at estimating directions and can use simple maps even if they are not oriented and they benefit from orientation points (Acredolo \& Bluestein, 1979; Blades \& Spencer, 1990). Objectives regarding orientation are explicitly mentioned only in the Slovene curricula, but only after the age of seven. Yet this is appropriately and constantly upgraded from grade to grade (from learning about opportunities of orientation in the environment (second grade), to knowing (third grade) and establishing (fourth grade) cardinal directions with sun, shadow and compass, from orienteering one selves with various drawings, charts and maps (fourth grade) to orienteering home landscape, Slovenia, Europe and world on the map and orienteering with a map and compass (fifth grade)). English Geography curriculum mentions orientation only through recommended activitythrough the objective of geographic vocabulary use, pupils should get to know compass directions (North/South). As mentioned, objectives in the English curriculum are written in the form of reference points that is why implementation and upgrade of orientation objectives depends on individual schools or teachers.

Next basic elements of cartographic literacy are cartographic signs. Although in both countries objectives associated with cartographic signs are not explicitly mentioned for pupils from seven years onwards, it should be emphasised that children remember the symbols even earlier on, if they are of high quality, concrete (images) and resemble the real world (Kulhavy \& Verdi, 2002). In classes it is reasonable to use maps of larger scale because here cartographic signs are more noticeable, less abstract and fewer in number what makes a map easier to read (Umek, 2001b). One of the cartographic signs is the coordinate grid. Reviewed curricula mention the use of the grid at about same age level (from seven to eleven years). Coordinate grid could be implemented (as it was the case in Slovenia for Mathematics) into lower grades because pre-school children can already comprehend an adjusted coordinate grid. This means that grids should be marked in colour and pictorial signs and in upper grades with numbers and letters (Blades \& Spencer, 2003). In the Slovene curriculum for Mathematics (Lipovec, Kmetič, Perat, Prinčič Rohler, Repovž, Senekovič et al., 2011) the grid is informatively introduced in the first grade, concretely in third grade, and in "cartography classes" not until the fourth grade. In England (in Geography and Maths) coordinate grid is foreseen for the children from seven to eleven years (The National Curriculum for England. Mathematics, 1999). Whether familiarization of this map component for both subjects is coordinated, of course, depends on the teacher.

Basic cartographic element that is most difficult to execute and comprehend is the land relief. The majority of pupils can understand it after the age of fourteen or fifteen. Objectives associated with land relief (at primary level both in England and in Slovenia) are mainly tied to notions related with landscape characteristics and ways of introducing these characteristics. With an appropriately adjusted land relief these basic cartographic elements can also be introduced to lower grades (use of pictorial signs for land relief) and in higher grades it can be upgraded with a colour scale and contour lines (e.g. drawing of contour lines while using a potato) (Umek, 2001b).

Map scale is also one of the map elements that are harder to understand. Evaluating distances can cause difficulties for children as well as for adults (Blades, Plaster, \& Spencer, 2003). It is best to use this concept with an understanding of notions decreased/increased and then with an understanding and measuring with a graphic scale. Graphic scale is the only explicitly mentioned objective associated to map scale in Slovene curriculum for Social studies (for fourth grade) that we came across while reviewing curricula. However there are numerous disparities regarding age level, when children should understand distances, ratios and scales. Child's understanding of scale should be dependent on the mathematical term ratio and on notion of distances that is why coordination with Mathematics is more than welcome here (Umek, 2001b).

\section{The Contents of the Objectives That Foresee Use, Reading, Drawing and Interpretation of Maps}

In order to develop child's familiarity with maps entirely, a child must have an opportunity to use maps, draw, read and finally interpret them in various contexts. Each program of teaching and learning must introduce these basic characteristics individually and at the same time find ways for their integration (Weeden, 2002).

In the English curriculum for Geography for the first educational period we have found five objectives associated with the use, drawing, reading and interpreting of maps of total of eight cartographic objectives. Meanwhile in the Slovene curriculum (for the same age period) they are only listed among basic cognitions.

Half of discussed objectives in the Slovene curricula (eleven of twenty-two cartographic objectives) are foreseen for the age period of seven to eleven years. It is similar in the second educational period of the English curriculum where there are more than half of discussed objectives (seven of ten cartographic objectives).

Objectives associated with the use of maps or objectives that "foresee a direct connection of map features and landscape features" (Weeden, 2002: p. 119), are already foreseen in both curricula for pupils up to seven years of age (in Slovenia latter is not stated among objectives but in basic cognitions). Similarly (up to seven years) drawing of maps is foreseen or objectives that "foresee coding of information into cartographic form" (Weeden, 2002: p. 119), but curricula do not pay them enough attention. Objectives associated with reading maps or objectives that "foresee decoding of map elements" (Weeden, 2002: p. 119) are being introduced earlier in England, namely before the age of seven, and in Slovenia only for pupils from nine year onwards.

For achieving cartographic literacy development of both receiving and giving information is essential. In her research Umek (2003) even found that in order to develop and comprehend cartographic literacy it is more efficient to make maps rather than just read them. Why? While drawing the child occupies more cognitive channels - graphomotor and visual skills 
(a child draws what he observes), a child is connected to the real world while drawing, gets to know a map in function, better understands basic elements of a map, directly experiences problems (which sign to use for fruits, how to draw a bench, etc.) and is more perceptive for various solutions.

While drawing maps pupils use active knowledge and passive in reading them. Therefore it is reasonable to consider drawing maps. Children are certainly motivated if classes are more diverse and intertwined with various methods that cover different cognitive types and ways of learning (Umek, 2001a).

In the reviewed curricula we did not come across objectives that would explicitly indicate map interpretation or objectives that "foresee the ability to connect adopted geographic knowledge with the observed features and map patterns" (Weeden, 2002: p. 119). This is of course understandable because most of thirteen year olds are at the level of basic reading techniques, and only at the age of fifteen they can proceed to the abstract level of working with maps. However younger pupils can also interpret appropriately adjusted maps to a certain extent (Umek, 2001b).

\section{Teachers’ Autonomy, Teaching Forms, Methods and Techniques for Teaching Initial Cartography in the Selected Countries}

School is becoming an increasingly autonomous and open learning environment where teachers have greater responsibility for content, organization and control of classes and as well as their professional development (Eurydice, 2008).

In England central school curriculum and standards authority determine minimal obligatory curriculum, plan learning contents, define attainment targets and determine forms and methods of knowledge assessment. Schools and teachers, as a rule, cannot change these decisions but individual schools are responsible for supplementation of contents (Eurydice, 2008). English curricula are an example of open curricula that allow schools and teachers a high level of autonomy and are ideal for creative teachers that search for innovative ways to reach objectives and find appropriate modern ways of teaching for themselves and pupils (Zupančič, 2008).

In Slovenia the program and curricula for primary school subjects is adopted by the Council of Experts of the Republic of Slovenia for General education. In the school year of 2011/ 2012 reformed curricula came into force in Slovenia and in many segments became more open. Curricula include general and operational objectives and contents, knowledge standards and didactic recommendations (from the field of achieving course objectives, individualisation and differentiation, crosscurricular connections and knowledge verification and evaluation). Detailed subject content is described in textbook sets which teachers choose from the list of preapproved textbooks (Eurydice, 2008).

Despite the reform, Slovene curricula, in comparison to the English ones, have a more detailed structure; they are more detailed in determining content, objectives and basic cognitions and so they guide the teacher through classes and help them with establishing the essence of the profession.

However despite the noted differences among the curricula teachers in England and Slovenia have a high level of autonomy in choosing teaching methods, forms and techniques. These are written rather in general, as some kind of recom- mendation, and similarly state:

- The use of various active and modern teaching methods and forms of work which gives pupils greater motivation and concentration during classes.

- Skilful planning of methods and work forms, adjusted to developmental characteristics of the pupils in a way that all can entirely and efficiently participate in classes (children with special needs).

- Active learning and researching of immediate surroundings with the teaching method of fieldwork.

- Promotion of the information-communication technology (ICT) use.

\section{Didactic Recommendations and Additional Help for the Teachers of Cartographic Literacy}

Despite of Slovene curricula reform, cartographic literacy in the first triad is given too little attention as well as on the content level as on didactic recommendations level. On the contrary the recommendations in the Social studies curriculum (second triad) prove that the authors have paid much more attention to cartographic literacy. They have covered all the criteria that we have analysed in this article (i.e. instructions for reading and drawing maps, basic components of cartographic literacy, broadening of spatial orientation, basic teaching method-fieldwork, use of pictorial material, comparison of the latter with maps, simplification of over exacting maps, etc.). With appropriate adjustment all of the above could be implemented in lower grades as well.

In the English Geography curricula there were no didactic recommendations directly associated with cartographic literacy.

Understanding of maps is mentioned in general, as well as use of ICT, meaning of real problem use and with that the development of pupil's research skills for solving these problems as well as inside as outside of classroom.

We can conclude that in Slovenia Social studies curriculum (in comprehending cartographic literacy) is of great help to the teachers and that in Slovene curricula there is a greater emphasis to the cartographic literacy despite of late implementation to classes.

While reviewing literature we came across some suggestions for teaching cartography:

- Activities associated with maps, "real" tasks and authentic instructions are a promising way of teaching exacting skills. Such knowledge has a personal note, places itself in the long-term memory and is generally not forgotten (Kulhavy \& Verdi, 2002).

- Maps in textbook sets represent either primary message of substantiation of information, can entirely replace text, but often they are only a visual decoration (Umek, 2001a). If a map is designed with an intention and is properly used in classroom, then it can serve as a tool that facilitates learning and enables acquirement of meaningful and relevant information during the learning process (Kulhavy \& Verdi, 2002).

- Children's literature sparks the imagination of children and inspires meaningful teaching. With listening or reading stories children can explore geography through literature. Use of children's literature as a source of teaching basic geographic notions enables children an understanding of geography that is composed of real people, places and occur- 
rences (Lin, Vasilijev, \& Zeitler Hannibal, 2002).

- Teacher's knowledge of ICT is important because proportionally with his ability to use this technology the use of ICT activities and their inclusion into classes increases (Umek, 2001a).

We can conclude that teachers should use appropriately adjusted maps for classes. It would be of great help if they were already appropriately adjusted in the textbook sets. It frequently occurs that maps in textbooks, workbooks and atlases are too exacting and as such perhaps tedious to pupils. Latter can be eliminated with the appropriate adjustment of basic cartographic elements, with combinations of maps and various picture materials, with intertwining of drawing and reading maps, with consistent use of charts (precise titles, presence and combination of various scales, map legend, date and source of data), with various presentations of number of layers of data, etc.

\section{Conclusion}

English curriculum is an example of an open curriculum that provides guidelines, global objectives, and core content and broadly sets basic cognitions at the end of individual educational period. As such it certainly does not pay much attention to objectives or to didactic recommendations for the cartographic literacy. In England the introduction and upgrade of cartography and appropriate cross-curricular connection greatly depends on individual schools or teachers. Slovene curriculum has a more detailed structure as the English one and as such pays much more attention to the cartographic literacy, but it introduces it (too) late. With appropriate adjustment certain objectives could be introduced in earlier classes and the introduction of certain content could be more adjusted with other subjects.

The quality of teaching is the most important factor in raising the educational level and realizing Lisbon objectives. That is why many European countries have increased professional autonomy of the teachers and enabled them a more flexible fulfilment of increasing number of work obligations (Eurydice, 2008). More open a curriculum is, greater autonomy it provides for the teachers at the level of content, level of difficulty (deepening of content), work forms and in didactic approaches of learning and teaching. But with increase of teacher's autonomy his level of professional qualification for a responsible planning and implementing of educational work should also "grow". This also places greater responsibility to the educational system at Faculties of Education and additional professional training of teachers.

Whether teachers at primary level are aware of the importance of cartographic literacy as a part of functional literacy and whether they are appropriately trained for this kind of literacy is certainly a question of further research.

Teacher with lack of appropriate knowledge on cartographic literacy in combination with an open curriculum pays far less attention to this topic during classes.

That is why teacher training and paying attention to cartographic literacy either in curricula or in textbook sets is of great impotence and therefore slightly concretely sets objectives and slightly more guided teachers are very important for cartographic literacy.

\section{REFERENCES}

Acredolo, L., \& Bluestein, M. (1979). Developmental changes in map reading skills. Child development, 50, 691-697. http://dx.doi.org/10.2307/1128934

Blades, M., \& Spencer, C. (1990). The development of 3 to 6year-olds'map using ability: The relative importance of landmarks and map alignment. Journal of Genetic Psychology, 151, 181-194. http://dx.doi.org/10.1080/00221325.1990.9914653

Blades, M., \& Spencer, C. (2003). Young children's ability to use coordinate references. Journal of Genetic Psychology, 150, 5-18. http://dx.doi.org/10.1080/00221325.1989.9914570

Blades, M., Plester, B., \& Spencer, C. (2003). Children's understanding of aerial photographs. Children's Geographies, 1, 281-293. http://dx.doi.org/10.1080/14733280302197

Budnar, M., Hus, V., Kerin, M., Kos, D., Mirt, G., Raztresen, M., \& Umek, M. (2011). Učni načrt. Program osnovna šola. Družba (Curriculum. Primary school educational program. Social studies.). Ljubljana: Ministrstvo Republike Slovenije za Šolstvo in Šport, Zavod Republike Slovenije za Šolstvo.

Eurydice (2008). Ravni avtonomije in odgovornosti učiteljev v evropi. Ljubljana: Ministrstvo za Šolstvo in Šport.

Kolar, M., Kostanjšek, R., Krnel, D., Pertič, M., Umek, M., \& Velkavrh, A. (2011). Učni načrt. Program osnovna šola. Spoznavanje okolja (Curriculum. Primary school educational program. Environmental studies.). Ljubljana: Ministrstvo Republike Slovenije za Šolstvo in Šport, Zavod Republike Slovenije za Šolstvo

Kulhavy, R. W., \& Verdi, M. P. (2002). Learning with maps and texts: An overview. Educational Psychology Review, 14, 27-46. http://dx.doi.org/10.1023/A:1013128426099

Lin, Q., Vasiliev, R., \& Zeitler Hannibal, M. A. (2002). Teaching young children basic concepts of geography: A literature-based approach. Early Childhood Education Journal, 30, 81-86. http://dx.doi.org/10.1023/A:1021292900592

Lipovec, A., Kmetič, C., Perat, Z., Prinčič Rohler, A., Repovž, B., Senekovič, J., et al. (2011). Učni načrt. Program osnovna šola. Matematika (Curriculum. Primary school educational program. Mathematics.). Ljubljana: Ministrstvo Republike Slovenije za Šolstvo in Šport, Zavod Republike Slovenije za Šlstvo.

The National Curriculum for England. Geography (1999). London: Department for Education and Employment, Qualification and Curriculum Authority. www.nc.uk.net

The National Curriculum for England. Mathematics (1999). London: Department for Education and Employment, Qualification and Curriculum Authority. www.nc.uk.net

Umek, M. (2001a). Kartografsko opismenjevanje v osnovni šoli. Ph.D. Thesis, Ljubljana: University of Ljubljana.

Umek, M. (2001b). Teoretični model kartografskega opismenjevanja v prvem triletju osnovne šole. Ljubljana: Faculty of Education.

Umek, M. (2003). A comparison of the effectiveness of drawing maps and reading maps in beginning map teaching. International Research in Geographical and Environmental Education, 12, 18-31. http://dx.doi.org/10.1080/10382040308667510

Verhetsel, A. (1994). The world in our hands: An experimental programme focusing on students' ability to represent and structure spatiality. Geographic and Environmental Education, 3, 45-55. http://dx.doi.org/10.1080/10382046.1994.9964942

Weeden, P. (2002). Teaching about language of maps. In M. Smith (Ed.), Aspects of teaching secondary geography (pp. 118-127). London \& New York: Routledge Falmer. http://118.97.161.124/perpus-fkip/Perpustakaan/Pendidikan\%20\&\%2 0Pengajaran/\%5BMargaret_Smith\%5D_Aspects_of_Teaching_Seco ndary_Geo\%28BookFi.org\%29.pdf

Zupančič, T. (2008). Likovni kurikul-Primerjava konceptov v luči prenove učnega načrta za likovno vzgojo. Revija za elementarno izobraževanje, 1, 33-44. 